\title{
New Public Management (NPM) in The Changing Status of Higher Education Institution in Indonesia
}

\author{
Muhammad \\ Universitas Islam Negeri Walisongo Semarang, Indonesia \\ muhammad@walisongo.ac.id
}

\begin{abstract}
Global competition among universities in the world has become more challenging over years. This makes it demanding not only for universities in Indonesia to create positive improvements but also for the government to adapt with its innovations and policy initiatives. Meanwhile, New Public Management approach which was initially introduced in 1990s has been proposing administrative reforms on the old inefficient bureaucracy. In response to this, universities along with the government have been incorporating some aspects of The New Public Management theory in order for them to strive in global competition. This study seeks to analyze the changing status of Indonesian universities. It further discusses how some aspects of New Public Management are incorporated in university's administration. This Indonesian case study argues that NPM values has influenced the changing system of universities in Indonesia. NPM still exists partially if not fully, in Indonesian universities despite the problem of public acceptance responding to the government's policy on university reforms.
\end{abstract}

Keywords: new public management; university management; Indonesian policy.

\section{Abstrak}

Kompetisi global antar universitas di dunia menjadi semakin menantang. Hal ini menuntut tidak hanya universitas tetapi juga pemerintah untuk beradaptasi dengan inovasi dan inisiatif kebijakan. Sementara itu, pendekatan New Public Management yang muncul pada era 1990an menawarkan reformasi administrasi pada birokrasi yang kolot dan tidak efisien. Merespon ini, universitas bersama dengan pemerintah sudah mulai mengakomodasi beberapa aspek dari teori New Public Management agar mereka dapat bersaing di kompetisi global. Studi ini berusaha menganalisis perubahan status universitas di Indonesia. Lebih jauh lagi, studi ini mendiskusikan bagaimana beberapa aspek New Public 
Management terakomodasi pada administrasi universitas. Studi kasus pada Indonesia ini berargumen bahwa nilai-nilai NPM mempengaruhi pergantian sistem universitas di Indonesia. NPM ada setidaknya sebagian pada universitas di Indonesia terlepas dari masalah penerimaan publik terhadap kebijakan pemerintah dalam reformasi universitas.

Kata Kunci: manajemen umum baru; manajemen perguruan tinggi; kebijakan Indonesia.

\section{Introduction}

The management of public universities under national government has been challenged in order for universities to compete in global education. The issue is independence from national politics and autonomy of university management so that university can independently create initiatives to improve its quality. This leads to some aspects of New Public Management, one of them is privatization. Subsequently, a new policy namely Badan Hukum Milik Negara (BHMN), a State-owned Legal Entity, was established granting few universities status in which university can operate without interference from government. Based on Government Law No. 61 year 1999, four universities were given the status of BHMN; University of Indonesia, Gadjah Mada University, Bogor Institute of Agriculture, and Bandung Institute of Technology (EP-Nuffic, 2015).

The establishment of this policy was surely controversial in Indonesia. Public challenges this policy by considering it as commercialization in Indonesian education (Putra, 2015). In fact, this might be true as the tuition fee of these universities has tripled since the establishment of this policy. Other counter argument against this policy is an article in national constitution mandating that education for every citizen is government's responsibility (MWA-WM ITB, 2015).

Therefore, government revoked the policy and changed the status of these universities. After the status of BHMN, these universities are then given the status of Badan Layanan Umum (BLU), a Public Service Agency. Under this status, universities are considered as special bodies within government delivering higher education services for public (Republik Indonesia, 2013). However, this new status of university was no different from the previous status making it hard for universities to improve themselves independently. Therefore, the status of these 
universities was changed again into Perguruan Tinggi Negeri - Berbadan Hukum (PTN - BH), a State owned Higher Education with Legal Entity allowing them to operate with limited flexibility (MWA-WM ITB, 2015).

This study uses literature research method with qualitative approach to analytically describe why higher education system in Indonesia shifted back and forth and how this shifting status affects changes in university management. This paper will further analyze the use of NPM values in the shifting system of higher education in Indonesia. This study argues that NPM has played role in the shifting of higher education system in Indonesia. The problem of applying NPM in Indonesian education system is public acceptance. However, despite of lacking in public acceptance, NPM still exists in its own way in higher education system in Indonesia.

\section{New Public Management in Higher Education}

New Public Management emerged as a response to the inefficient old bureaucracy. NPM was firstly used by Hood in 1991 referring to an intentional administrative reforms by government (Christensen, 2003). Its important aspect is asserting economic values into public management to become more professional (Christensen, 2003). From this understanding, NPM has been developed in many countries delivering some new aspects different from the old public management. The aspects of NPM then includes privatization and decentralization, measurement and quantification, market mechanism in public service delivery, etc. (Pollitt, 2003). These aspects of NPM are developed and applied differently in many countries.

In higher education sphere, NPM has also managed to bring some debatable issues. Christopher and Leung (2015) argued that frequently, universities are slow in embracing corporate change. Therefore, many universities that embrace NPM are adopting marketing values and processes especially when government decreased education expenditures such as subsidies and research funding (Holbrook, 2004). In Australia, the adoption of NPM features more accountability and responsibility in university management by involving various mechanisms such as measurement, emphasis on output, a shift to decentralization, and so on (Christopher \& Leung, 2015). However, it also argued that commercialization of higher education has decreased 
academic values such as academic freedom, intellectual integrity, and scholarly values (Holbrook, 2004). This controversial issue of applying NPM values in higher education has also emerged in many countries including Indonesia.

\section{Method}

This study uses a qualitative approach to critically analyze the changing status of Indonesian universities. It further explores the reasons behind the shifting of the university status. It will continue to analytically describe how the changing status influence the university management in general. This study particularly uses literature research to gather relevant articles including journal, news, and government reports to support the arguments. This research further uses the theory of New Public Management depicted in many literatures. This theory will especially analyse the incorporation of some values and reasons behind the university demands, reforms, and changing status.

\section{Higher Education System in Indonesia}

Higher education in Indonesia has long been delivered by various providers. It includes both private and public organizations. Most of public higher education is managed by two ministries, namely Ministry of Higher Education and Ministry of Religious Affairs. While Ministry of Religious Affairs manages religious based universities, institutes, and academies in many regions in Indonesia, Ministry of Higher Education runs higher education institutions in general including the biggest and most favorite universities in Indonesia. Besides Ministry of Higher Education and Ministry of Religious Affairs, other ministries such as Ministry of Finance, Ministry of Defense, Ministry of Transportation, and others also manage a few higher education institutions across the country. However, Ministry of Higher Education has the authority to set standard complied by all higher education institution including those which are managed by private sector (Wicaksono \& Friawan, 2008).

The variety of umbrella institution providing higher education has some implications. Those which are under management of ministries called PTN (State-owned / public higher education institution) are entitled government subsidies taken from National Budget (Wicaksono \& Friawan, 2008). It means that most of financial cost of those universities 
are of state's responsibilities, making education cost paid by students much less than private institutions. The employees of those public institution are also considered state's public servants (Wicaksono \& Friawan, 2008) making all lecturers and management employees are regulated under ministry of public servants.

From financial perspective, public universities do not have autonomy to manage their own finance. As mentioned above, most of the university budget comes from national budget. Universities are allowed to draw tuition fee from its students for its education services but it needs to be approved and regulated by Ministry of Higher Education and Ministry of Finance. The student's tariff and all non-tax revenue must first be delivered to national treasury. All university's expenditures must be planned and proposed to ministry of higher education and when it comes to execution of expenditure's plan, universities must follow the mechanisms through special commission on national revenue and expenditure. Further, all university assets belong to the state, therefore, asset management must have approval from Ministry of Higher Education. Lastly, as any other units of government, universities also have to follow audit mechanism such as internal audit by Satuan Pengawas Internal (SPI), an internal control unit, and external audit by Badan Pemeriksa Keuangan (BPK), an Indonesian audit board (MWA-WM ITB, 2015).

Therefore, public higher education under status 'PTN' is simply a ramification under ministry institutions. They have the same vision and mission as ministries do. It also implies that management of all public higher education are centralized mainly on the Ministry of Higher education (Wicaksono \& Friawan, 2008). University counselors are appointed by ministers and university officials' appointment have to be approved by ministers. All matters including curriculum has to be approved by ministries (MWA-WM ITB, 2015). PTN universities simply lack of autonomy to manage themselves.

\section{BHMN (State Owned Legal Entity)}

In order to solve the lack of autonomy among universities, a new institution was introduced namely BHMN. BHMN was a status given to some public universities were granting these universities with autonomy from Ministry of Higher Education (Republik Indonesia, 2009). There 
were only four universities that are given the status of BHMN, considering the fact that these are the most reputable universities in Indonesia with good management; Gadjah Mada University, University of Indonesia, Bogor Agricultural Institute, and Bandung Technological Institute (KOPERTIS, 2016). The basic idea was that by giving them autonomy, universities could progress themselves in global competition (Nurdin, 2009).

The autonomy given to these universities were quite reformative. By earning that status, these universities had wide autonomy in both academics and non-academics (Putra, 2015). These universities were no longer units under Ministry of Higher Education but were institutions that had their own vision. They were simply non for profit organization providing higher education and research service. Institutionally, they were no longer accountable to the Ministry of Higher Education, but to their own senate called MWA (Republik Indonesia, 2009). This senate was an institution assembling stakeholders that include professors, administrators, students, and representative of the ministry of higher education (Republik Indonesia, 2009). Therefore, this senate was the highest authority regulating these universities.

The financial management of these universities were also different from other higher education institutions. The budget planning was no longer approved by the Ministry of Higher Education but by the senate (Republik Indonesia, 2009). Universities also had the freedom to manage their revenue and expenditure as well as to determine tuition fee. Universities also have the authority to manage the assets without approval of the Ministry of Education (MWA-WM ITB, 2015). Nonetheless, these universities still belonged to the state, therefore, besides internal audit of the senate, they also need to follow audit mechanism by BPK and SPI.

From curriculum perspective, the autonomy is widely applied to these universities. Universities could also decide to open or close certain programs (Putra, 2015). It fully depended on the decision of the senate without having approval from the Ministry of Education. However, during period of BHMN, there was no report that this discretion had been used to promote or diminish a certain department/study program.

However, the establishment of BHMN was controversial. Many parties especially students were against the idea of privatization and 
commercialization of education institution (Susanti, 2011). Indeed, financial autonomy has made universities also focused on getting other sources of revenue. The tuition fee of these universities therefore rocketed. Further, this high tuition fee had been problematized as not giving equal access to students from lower level economy (Nurdin, 2009). Finally, National Highest Court of Constitution abolished the system of BHMN because providing equal access for education is considered as state's responsibility (Mahkamah Konstitusi Republik Indonesia, 2012), therefore, the quasi privatized universities could not be justified under constitution.

\section{BLU (Public Service Agency)}

After status of BHMN was abolished, these universities then gained its status as Badan Layanan Umum (BLU), a public service agency, along with some other universities. Until 2012, there were 35 universities given the status of BLU. Later, some of these universities have been changed into other legal status, therefore, currently, there are only 24 BLU universities (KOPERTIS, 2016). BLU is government institution formed to provide public service with certain tariff without commercial intention (Republik Indonesia, 2013). Therefore, university budget comes from two different sources, national budget and service tariff from public (MWA-WM ITB, 2015). The status of BLU equals universities in the same line as other governmental service-providing agency such as hospitals. They are still under the command of the ministry of higher education, even the mission and the vision of universities under this status have to be the same as the ministry (Republik Indonesia, 2013).

Generally, BLU is formed by government to facilitate public service in changing environment. Therefore, certain amount of autonomy was given to this type of government body. However, the autonomy given to this kind of government body is limited to include only budget management from non-national budget which are from tuition fee and other revenues (MWA-WM ITB, 2015). Even the tuition fee has to be approved by the ministry of education (KOPERTIS, 2016). Other than that, everything is similar to that of universities under the status PTN.

The application of BLU status to these universities does not make much difference. Indeed, the tuition fee that has to be paid by students is controlled by government. Therefore, the responsibility to maintain 
tuition fee to still be affordable, goes back to the government. However, the disadvantages of not having sufficient autonomy also experienced by universities under PTN status. Therefore, demand for change remains.

\section{PTN - BH (State Higher Education with Legal Entity Status)}

In 2013, three pioneer universities were given the legal status of PTN - BH, Bandung Institute of Technology, University of Indonesia, Gadjah Mada University, and Bogor Institute of Agriculture. Currently, these are universities under the status of PTN - BH along with other seven universities (KOPERTIS, 2016). Therefore, there are three different status of public higher education institutions, 11 PTN - BH, 24 PTN - BLU, and others are simply PTN under previous management system (KOPERTIS, 2016).

The status PTN - BH is established to accommodate the need of autonomy for some universities particularly those which experienced the status of BHMN. The BLU status is considered insufficient in order for these universities to improve themselves. Basically, the status PTN -BH is not different from BHMN. PTN - BH has its own vision and mission, senate, and autonomy both in academic and non-academic matters(MWA-WM ITB, 2015).

However, there are two main distinguished characteristics of PTN - $\mathrm{BH}$; the first is the stressing on morality that obliges universities to have moral consideration on every decision(Republik Indonesia, 2013). Secondly, the ministry of higher education is in consultative position especially when it comes to determining tuition fee. Even though PTN BH universities can decide the amount of tuition fee, they need to comply with technical guide created by ministry of higher education (Republik Indonesia, 2013). Further, they need to consult it with the ministry considering economic capacity of their students and their parents' economic condition (Trisnantoro, 2016). Therefore, universities have autonomy with strict limitation when it comes to tuition fee. It appears that this particular regulation exists to solve problems that made BHMN diminished. In other words, BHMN's values are incorporated in PTN-BH.

\section{Privatization and the State's Responsibility}

The tension regarding the shifting status of university is about privatization. BHMN was criticized as another form of privatization when 
government gave up control over education institutions (Nurdin, 2009). Critics mentioned that education is basic need of Indonesian citizens, therefore, state-owned universities cannot be privatized (Susanti, 2011). On the other hand, supporters of BHMN defended that the status change does not necessarily mean privatization (Nurdin, 2009). BHMN status would indeed reduce government control over universities but the institutions basically still belong to the state. Overall, the term privatization in education sphere is unlikely in current situation in Indonesia.

The changing university status (BHMN and PTN BH) also raises questions about government's responsibility. The constitution mentions that states are obliged to provide access for all citizens to enjoy education (Mahkamah Konstitusi Republik Indonesia, 2012). The interpretation can be that government's responsibility to provide all education services. On the other hand, the constitution does mention specifically about government responsibility in the provision of basic education but not higher education. Therefore, whether government should provide higher education for all citizens is actually contestable. It appears that the concept of distinguishing responsibility from provision does not apply in current Indonesian higher education context. However, as Susanti (2011) argued, the status BHMN and PTN - BH indicates an obvious reduction of government's responsibility and commitment to higher education. Therefore, the highest court of constitution has already determined that affordable higher education is governments' responsibility.

\section{Commercialization Versus Equal Access}

Another controversial consequence of the changing status to either BHMN or PTN - BH is financial autonomy. By giving universities this status, government no longer provides all necessary budget to improve qualities of these universities. Government still gives financial aids to these universities. However, the amount of the subsidies would certainly be reduced (Prasetya, 2005). It practically means that financial autonomy is not only about the freedom of universities to manage their expenditures, but also about universities having to manage themselves to gain revenue from other sources.

Therefore, financial autonomy leads university to become more commercial. There are two practical ways for universities to obtain more 
funds. The first one is to establish a commercial unit to gain profits for university (Putra, 2015). Because of this for-profit units, mission drift (Considine, O'Sullivan \& Nguyen, 2014) could also happen to these universities when market values are applied to non for profit institutions. When universities have to consider profit as one of their important goals, the academic values could be undermined especially when universities tend to focus on getting profits to survive (Holbrook, 2004).

Another approach for university to survive financial autonomy is to raise tuition fee making it harder especially for students from lowincome families. Susanti (2011) reported that the tuition fee of BHMN universities has become more expensive than that of private universities in Indonesia. Commercialization of universities treats students, as what Holbrook (2004) called it, as customers rather than citizens that deserve equal access. Therefore, BHMN universities are available for those who can afford to pay the tuition fee (Susanti, 2011). Those who come from low- income families would be more marginalized by this commercial management. Therefore, because of this particular inequality to reach higher education, BHMN was abolished by the highest court of constitution (Mahkamah Konstitusi Republik Indonesia, 2012).

However, the establishment of the status PTN - BH does not erase the problem of raising tuition fee. Financial autonomy persists in PTN $\mathrm{BH}$ in which universities make another arrangement to raise tuition fee under approval of ministry of higher education (Republik Indonesia, 2013). Universities still need additional revenue because subsidy is still reduced. However, to assert control on tuition fee, the ministry has its own mechanism, called UKT (single tuition fee). In UKT system, tuition fee is differed among students based on their families' income. Students from high income families will have to pay higher tuition fee. On the other hand, those who are from low income families will pay less and even free (Prasetya, 2013). In the end, this mechanism is also controversial because universities might prefer to accept those who can pay higher in order to fulfill universities' financial needs. Therefore, even though this mechanism is still running, protests towards UKT is also still going.

\section{The Need of Autonomy for Higher Education}


In Indonesian context, the need of autonomy for higher education institutions is always related to the intention to improve quality. Currently, positions of Indonesian universities in competitive international benchmarking are really low. The highest ranks of universities in Indonesia are University of Indonesia $\left(325^{\text {th }}\right)$, Bandung Institute of Technology $\left(401^{\text {st }}\right)$, and Gadjah Mada University (501 $\left.{ }^{\text {st }}\right)$ (QSTopUniversities, 2016). It was argued that one of the reasons to this is the centralization in the old management system (PTN) in every aspect including curriculum, financial, asset, and employee management (Prasetya, 2005). Therefore, giving autonomy widely to universities provides opportunities for them to create necessary change and efforts to improve their quality.

However, the concept and the application of higher education autonomy in Indonesia are multifaceted. Especially in the case of BHMN, autonomy is defined and applied differently by various actors (Prasetya, 2005). Lecturers may define it as a choice in designing curriculum and also a raise of their salaries although it will affect in the amount of tuition fee. Students may as well perceive it differently in ways that they are going to be involved in the senate and that they are free to oppose raising tuition fee and other university policies. Ministry of finance might interpret it as to decrease university budget (Prasetya, 2005).

Another issue raised in the autonomy of higher education institution is accountability and control mechanism. As mentioned before, in the status BHMN, universities are no longer accountable to the ministry of higher education. Rather, the accountability of university management is towards the university senate (Republik Indonesia, 2009). It indicates that ministry of higher education is losing control over universities. Again, students' protest towards this issue is that government should have control over universities especially when it comes to tuition fee and equal access for those coming from low income families (Nurdin, 2009). However, the fact about government control in BHMN system was different. In the case of Gadjah Mada University under BHMN status, even though the rector is appointed through election in the senate, the representative of the ministry of higher education which was the minister himself, had deciding vote (Humas UGM, 2007). But, when it comes to other aspects of decision such as tuition fee, the ministry of 
higher education gave its vote to the senate. This blurred definition of autonomy made the BHMN system failed and finally abolished.

However, the need for autonomy for these universities persists. Indeed, giving up government's control over education institutions seems quite undesirable. Protests successfully achieved victory by the abolishment of BHMN. However, when the status of BLU has failed to answer the need of decentralization, the system changed back and granting some universities a new status of PTN- BH. Nonetheless, the status is still controversial because universities cannot enjoy full autonomy so that they can perform well. On the other hand, even though the ministry of higher education accommodated the need for tuition fee control by establishing 'single tuition fee' system, many students still cannot enjoy full equal access because universities logically would prefer students who can afford high tuition fee.

\section{Conclusion}

NPM has clearly been adopted in higher education system in Indonesia. Some aspects of NPM such as privatization and decentralization have managed to become controversial issues in university status. Universities are demanded to become more competitive in globalization era. Therefore, demand for universities to have autonomy persists. Even though critics have succeeded to temporarily bring back some universities to older status, it managed to shift the status into something new. It appears that the term privatization and commercialization is undesirable in the context of Indonesian higher education system based on Indonesian constitution. However, the practices of NPM aspects still continue under the term limited autonomy under the ministry of higher education control.

\section{References:}

Christensen, T 2003, 'Transformative Perspective on Administrative Reforms', in Christensen, T \& Laegreid, P (eds.), New Public Management: The Transformation of Ideas and Practice, Ashgate, Hampshire.

Christopher, J \& Leung, P 2015, 'Tensions Arising from Imposing NPM in Australian Public Universities: A Management Perspective', 
Financial Accountability \& Management, vol. 31, no. 2, pp. 171191.

Considine, M, O'sullivan, S \& Nguyen, P 2014, 'Mission drift?: The third sector and the pressure to be businesslike: Evidence from job services Australia', Third Sector Review, vol. 20, no. 1, pp. 87-107.

Holbrook, MB 2004, 'Universities in the Marketplace: The Commercialization of Higher Education', Journal of Macromarketing, vol. 24, no. 1, pp. 68-74.

Humas Ugm 2007, Amien Rais : Pemilihan Secara Langsung Rektor UGM Tidak Mungkin Dilakukan pada Periode ini

viewed October 3rd, https://ugm.ac.id/id/berita/1444amien.rais...pemilihan.secara.langsung.rektor.ugm.tidak.mungkin. dilakukan.pada.periode.ini

Kopertis 2016, Seputar PTN-BH, PTN-BLU, PTN-Satker dan PTN-Baru, viewed September 24th,

http://www.kopertis12.or.id/2016/05/16/seputar-ptn-bh-ptn-bluptn-satker-dan-ptn-baru.html

Mahkamah Konstitusi Republik Indonesia 2012, 'PUTUSAN Nomor 103/PUU-X/2012'.

Mwa-Wm Itb 2015, Transformasi Perguruan Tinggi Menghadapi Era Globalisasi, viewed August 15th, http://mwawm.itb.ac.id/transformasi-perguruan-tinggi-menghadapi-eraglobalisasi-3/

Nurdin 2009, 'Pro-Kontra Undang Undang BHP dalam Konteks Mutu Pendidikan', JURNAL Administrasi Pendidikan, vol. IX, no. 1, pp. 34-50.

Pollitt, C 2003, 'The 'New Public Management' - revolution or fad?', in Pollitt, C (ed.), The Essential Public Manager, Open University Press/McGraw-Hill Education, Maidenhead.

Prasetya 2005, Soal Rencana Perubahan Status Unibraw, Rektor Tepis Ada Privatisasi, viewed September 15th, http://prasetya.ub.ac.id/berita/id/html/9740

Prasetya 2013, Pembahasan Polemik UKT, viewed October 5th, http://prasetya.ub.ac.id/berita/Pembahasan-Polemik-UKT-13174id.pdf

Putra, GRN 2015, Politik Pendidikan: Liberalisasi Pendidikan Tinggi

Periode 2000-2012 viewed October 5th, http://lib.ui.ac.id/naskahringkas/2015-08/S44687-

Galih\%20Ramadian\%20Nugroho\%20Putro

Qstopuniversities 2016, Universitas Indonesia 
viewed October 5th,

http://www.topuniversities.com/universities/universitas-

indonesia/undergrad

Republik Indonesia 2009, 'UNDANG-UNDANG REPUBLIK INDONESIA

NOMOR 9 TAHUN 2009 TENTANG BADAN HUKUM PENDIDIKAN

(Law No. 9 about Education Legal Entity)'.

Republik Indonesia 2013, 'PERATURAN PEMERINTAH REPUBLIK

INDONESIA NOMOR 58 TAHUN 2013 TENTANG BENTUK DAN

MEKANISME PENDANAAN PERGURUAN TINGGI NEGERI BADAN

HUKUM (Government Law No. 58 / 2013 about Form and

Mechanism of PTN-BH)'.

Susanti, D 2011, 'Privatisation and marketisation of higher education in Indonesia: the challenge for equal access and academic values', Higher Education, vol. 61, no. 2, pp. 209-218.

Trisnantoro, L 2016, Manfaat Perubahan Menjadi PTN-BH, viewed September 30th, http://www.manajemenpendidikantinggi.net/index.php/compone nt/content/article/10-halaman/114-manfaat-perubahan-menjadiptn-bh

Wicaksono, TY \& Friawan, D 2008, Recent Developments in Higher Education in Indonesia: Issues and Challenges, viewed September, 25th, http://pressfiles.anu.edu.au/downloads/press/p148581/pdf/ch082.pdf 